\title{
Technology Transfer Opportunities: Partnership Opportunities Available at the USGS
}

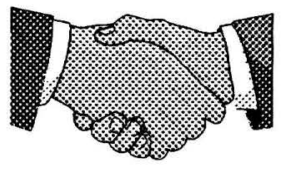

The following are USGS research projects offering an opportunity for Cooperative Research and Development Agreement (CRADA) partnerships. A CRADA is an agreement between one or more Federal agencies and one or more non-Federal agencies to work together in research or developmental activities. CRADAs permit both partners to share information in a protected environment and offer incentives to the non-Federal partner(s) to commercialize the resulting product of the effort.

\section{Development of a Computer Program to Quantify Drainage-Basin Characteristics} The USGS is looking for partners to develop an interactive version of Basinsoft, a computer program developed by USGS scientists to analyze and quantify characteristics of drainage basins. Companies partnering with the USGS in this effort would provide expertise to develop menus to make the program userfriendly.

\section{Automated Feature Extraction and Classification System for Images}

The USGS is seeking a commercial partner to continue work in this area, exploring the use of automated feature extraction and classification from image sources.

\section{Computer Program for Calculating Mineral Size Distributions From X-Ray Diffraction Data}

Scientists at the USGS have developed a computer code that calculates crystallite size distributions and strain for minerals from X-ray diffraction data. The program may be useful to many types of manufacturers who use or synthesize clay-size crystalline materials.

\section{National Geospatial Data Framework} USGS is seeking a partner for collaborative development of the framework. Initial efforts call for the implementation of a national geospatial data framework by the year 2000 and for the establishment of a process to maintain these data in the decades beyond 2000 .

\section{Selenate Removal From Waste Water} This patented method is available for license from the USGS and for collaborative development. Microbial agents are used to remove nitrates and toxic selenium compounds from waste water.

\section{Print-on-Demand Technology}

The USGS is searching for partnerships with innovative companies who possess the technical expertise and resources to further commercially develop USGS print-on-demand technology.

USGS Assistance to State Businesses The USGS is seeking cooperative partnerships with state business assistance organizations who can help match USGS technologies with the state's businesses, particularly small companies, who may be interested in adopting, using, and commercializing these technologies.

\section{Digital Raster Graphics}

Federal and non-Federal partnerships for costsharing, work-sharing, and data exchanges are sought for work involving a scanned image of a USGS topographic map that can be used to collect, review, and revise other digital data, 
especially digital line graphs (DLGs).

\section{Development of NeoChim Exploration \\ Technology}

USGS is seeking a commercial partner to test and further develop mineral, oil, and gas exploration technology that improves upon the Chim method as a cost-effective geochemical exploration technique.

\section{Development of Corrosion-Resistant Hydrothermal Cells}

Cooperative partnerships are sought to test and refine prototype corrosion-resistant hydrothermal cells that offer widespread potential applications in diverse industries and academia. This research involves highlycorrosive, high-temperature pressure systems such as nuclear and geothermal power, and petroleum.

\section{CD-ROM Training Program on the Hazards of Volcanic Ash to Aviation}

A CRADA partnership is being sought to refine and develop an interactive training system for alerting airline pilots to the hazards of volcanic ash and ash clouds.

\section{National Geochemical Database (NGDB)}

This database contains over 2 million records of diverse sample types collected during geochemical surveys by the USGS. Most samples are available for further analyses. Partners could assist USGS in developing products and uses for these data, perhaps in fields like agriculture, environmental hazard identification, and remediation.

Electronic National Atlas of the United States The USGS is designing a new "National Atlas" using electronic technology. Interested parties are encouraged to participate in creating and marketing this product in a combination of formats, including CD-ROM, printed maps, and the World Wide Web.

Physical and Chemical Properties of Natural and Synthetic Minerals and Rocks

The USGS is looking for collaborative partners to assist in the development of prediction models that explain how physical properties of natural and synthetic minerals and rocks vary with composition, internal structure, temperature, redox state and pressure.

Thermodynamic Properties of Minerals and Related Materials

The USGS has a wide array of techniques and equipment for sample characterization and measurement of thermodynamic properties of minerals and mineral materials. Cooperative partnerships in this area are encouraged.

Spatial Data Transfer Standard: FIPS 173-1 Cooperation with other government agencies, academia, and private industry is being sought by the USGS to transfer technology associated with the Spatial Data Transfer Standard (SDTS). SDTS is a means for moving spatial data between different computer systems.

National Water Quality Laboratory The USGS National Water Quality Laboratory analyzes water quality samples taken from ground and surface water located throughout the United States. Most of the sample analysis is conducted cooperatively with Federal, state and local agencies.

Hydraulic Laboratory, Hydraulic Laboratory Facilities Project, and Hydrologic Instrumentation Facility The USGS supports three unique facilities offering hydraulic and hydrologic testing. These facilities have been focal points of cooperative efforts with Federal, state and local agencies.

\section{Aquatic Contaminants in Colloidal Phases} and Humic Complexes

The USGS has developed sampling and isolation techniques to determine the size and chemical form of trace metals and organic contaminants in ground and surface waters. Materials obtained by these techniques can be characterized to assess chemical reactions responsible for the contaminant associations. The USGS wants partners to assist in developing this technology for uses in environmental remediation.

For More Information 
Additional information about these partnership opportunities or how to enter into a partnership with the USGS can be obtained by contacting:

Technology Transfer Office

U.S. Geological Survey, 104 National Center 12201 Sunrise Valley Drive

Reston, VA 20192

Tel: (703) 648-4450 Email:

tto@www.usgs.gov

FAX: (703) 648-5068 